\title{
KLAN KWIEKÓW JAKO PRZEDSTAWICIELSTWO CYGAŃSKIE A OBÓZ SANACYJNY W LATACH 1926-1935 W ŚWIETLE SANACYJNYCH I PRORZĄDOWYCH DZIENNIKÓW INFORMACYJNYCH
}

\author{
KWIEKS' CLAN AS THE REPRESENTATION \\ OF GYPSIES AND THE SANATION CAMP \\ IN THE LIGHT OF GOVERNMENT AND PRO- \\ GOVERNMENT NEWS BULLETINS (1926-1935)
}

\section{Abstract}

This article discusses the Kwiek family actions as the representation of Gypsies in close connection with political conditions. This clan appeared in public life during the leadership of the Pitsudski's governing block, and its activity was approved and accepted by the regime, which also adopted Gypsy leaders under country's consolidation although the Gypsies were included in Piłsudski's circle not officially. Nevertheless, solidification of representation of Gypsies' demands followed, which, by representing various centers, spread via government and pro-government press. The Roma could raise several issues that were most important to their community, achieving many benefits for the family itself and the Kwiek clan at the same time.

Key words: Gypsy representation; Gypsies; Kwieks' clan; Polish administration; Sanation regime

ALICJA ANNA GONTAREK Uniwersytet Marii Curie-Skłodowskiej, Lublin E-mail: alicja.gontarek@onet.pl

CITATION: Gontarek, A. A. (2017). Klan Kwieków jako przedstawicielstwo cygańskie a obóz sanacyjny w latach 1926-1935 w świetle sanacyjnych i prorządowych dzienników informacyjnych. Sprawy Narodowościowe. Seria nowa, 2017(49). https://doi.org/10.11649/sn.1307

This work was supported by the author's own resources. No competing interests have been declared.

This is an Open Access article distributed under the terms of the Creative Commons Attribution 3.0 PL License (creativecommons.org/licenses/by/3.0/pl/), which permits redistribution, commercial and non-commercial, provided that the article is properly cited. (C) The Author(s) 2017.

Publisher: Institute of Slavic Studies, Polish Academy of Sciences 


\section{Streszczenie}

Artykuł omawia działania rodziny Kwieków jako reprezentacji cygańskiej w ścisłym związku z uwarunkowaniami politycznymi. Klan ten w życiu publicznym pojawił się w okresie rządów obozu piłsudczykowskiego. Jego aktywność została uznana i zaakceptowana przez sanację, która w ramach konsolidacji państwowej przyjęła do siebie także liderów cygańskich, przy czym włączenie Cyganów w platformę piłsudczykowską nie miało charakteru oficjalnego. Niemniej dzięki temu doszło do krystalizacji postulatów przedstawicielstwa cygańskiego, które, reprezentując różne ośrodki, poprzez rządową i prorządową prasę mogło zabierać głos w najważniejszych dla ludności cygańskiej sprawach, osiągając jednocześnie wiele korzyści dla rodziny i klanu Kwieków.

Słowa kluczowe: Cyganie; cygańska reprezentacja; klan Kwieków; polska administracja; sanacja

\section{UWAGI WSTĘPNE}

$\mathrm{P}$ roblematyka cygańska w okresie międzywojennym jest tematem wciąż słabo rozpoznanym przede wszystkim ze względu na znaczne rozproszenie materiału źródłowego, zawartego głównie w prasie. Badania Jerzego Ficowskiego (1985, ss. 87104) wzmiankujące o związkach Cyganów z przedstawicielstwem politycznym państwa polskiego są jedynymi, które zagadnienie to poruszają. Wskazały one, iż klan Kwieków, wywodzący się z grupy Ketderaszy, któremu udało się po 1926 r. przy pomocy władzy państwowej zdominować Cyganów zamieszkałych na ziemiach polskich, próbował z wymiernym skutkiem restytuować tradycje monarchii cygańskiej z okresu I Rzeczypospolitej. W tym celu przyjął tytuł królewski, tudzież stosował inne mniej anachroniczne nazewnictwo na określenie swego zwierzchnictwa nad całokształtem życia cygańskiego na ziemiach polskich¹.

Zgoła odwrotną refleksją podzielił się Andrzej Mirga, który stwierdził, iż w II Rzeczypospolitej ludność cygańska była przedmiotem, a nie podmiotem historii: Cyganie uważani za grupę marginalną, a nawet zbędną, nie przedstawiali wymiernej siły politycznej i nie przejawiali ambicji politycznych. Jak stwierdził A. Mirga (1998, ss. 110, 116), sytuacja ta wynikała częściowo z braku ukształtowania w procesie dziejowym elity cygańskiej, zdolnej skutecznie wpływać na swój los lub o nim współdecydować. Konstatacja ta wynika z przeświadczenia, iż w okresie międzywojennym władze państwowe przejawiały nikłe zainteresowanie sprawami cygańskimi. Warto też zwrócić uwage na fakt, iż żaden z tych badaczy nie zdefiniował, co rozumie przez działania polityczne przywództwa cygańskiego w okresie międzywojennym².

Celem niniejszego artykułu jest weryfikacja powyższych stwierdzeń w oparciu o materiał prasowy - jedyne źródło, które aktywność Kwieków prezentuje w szerszej perspektywie. Choć działania klanu oceniane mogą być różnie, to nie podlega dyskusji wśród badaczy-cyganologów, iż środowisko to odcisnęło silne piętno na społeczności cygańskiej. Jak się zdaje, ten silnie rozgałęziony klan lub osoby, które za pomocą fałszywych dokumentów

\section{- . . -}

Jerzy Ficowski bardzo surowo oceniał poczynania Kwieków, jako uzurpatorów i „wyzyskiwaczy mas cygańskich", reprezentujących anachroniczną strukturę rządów, którą odrzucali sami Cyganie. Jego szkic na ich temat, choć niewolny od wielu usterek, jest pierwszą i jedyną dotąd oryginalną próbą zbudowania narracji historycznej na temat tego klanu.

2 Andrzej Mirga, odnosząc się do II RP, wspomniał dość enigmatycznie, iż w tamtym okresie „do głosu dochodziły zaczątkowe elity cygańskie. Często też były one inspirowane i wspierane przez niecygańskich sympatyków". Prawdopodobnie miał na myśli klan Kwieków (Mirga, 1998, s. 116). 
deklarowały do niego przynależność, tworzący w istocie odrębne ośrodki władzy, uchodził wówczas za jedyne gremium zdolne przemawiać w imieniu szerszych mas cygańskich.

Wobec braku jakiejkolwiek innej bliżej znanej elity cygańskiej tamtego czasu, zasadne jest więc pytanie, czy i w jakim stopniu Kwiekowie swą dominację nad innymi przedstawicielami cygańskimi zawdzięczali środowisku piłsudczykowskiemu, a także która ze stron, i pod wpływem jakich czynników oraz okoliczności, mogła być zainteresowana nawiązaniem kontaktu. Interesujące jest też, jakie były efekty bądź korzyści wzajemnych relacji.

Wybór źródła - sanacyjnych i prorządowych dzienników - uwarunkowany został tym, iż Kwiekowie, niezwykle aktywni, na arenę polityczną i do życia publicznego weszli w momencie, gdy obóz piłsudczykowski zdobył i umocnił swą władzę. Już sam ten fakt jest znamienny, wziąwszy pod uwage wpływ koncepcji konsolidacji państwowej na życie społeczno-polityczne w ówczesnej Polsce, a zatem na pojawienie się przedstawicielstwa cygańskiego w przestrzeni publicznej. Kwerendę źródłową zawężono do czołowych tytułów, wychodzących w Warszawie, w centrum życia politycznego, pod egidą piłsudczykowskiej władzy takich, jak "Gazeta Polska", będąca organem partyjnym Bezpartyjnego Bloku Współpracy z Rządem, i „Polska Zbrojna” (Seniów, 1998)³. Tytuły prorządowe reprezentuje zaś największy dziennik w ówczesnej Polsce, "Ilustrowany Kuryer Codzienny" („IKC”), wydawany od 1910 r. Ostatnia z gazet od 1926 r. związała się na trwałe, za sprawą jego redaktora - Mariana Dąbrowskiego, z obozem sanacyjnym (Bańdo, 2003, ss. 119-144; Borowiec, 2005). Stąd uznać ją można za sztandarowy dziennik prorządowy, który do wybuchu drugiej wojny światowej nieprzerwanie w kluczowych dla państwa polskiego sprawach stał się wykładnią poglądów środowiska piłsudczykowskiego (Władyka, 1979, s. 91)4. Ciągłość wszystkich gazet sprzyja badaniu wzajemnych relacji obu grup, rządowej i cygańskiej, oraz sposobów wzajemnej komunikacji. Szukając więc związków cygańskiego przedstawicielstwa z czynnikami politycznymi wywodzącymi się z obozu sanacyjnego, można stwierdzić, iż dzienniki te z pewnością stanowią właściwą płaszczyznę analizy podjętej problematyki.

Podejmując tę tematykę, autorka przychyla się do wniosków Waldemara Parucha (2001, ss. 71-118), iż zagadnienie mniejszościowe w obozie piłsudczykowskim istniało w tym kręgu wyłącznie na poziomie koncepcji, nie funkcjonowało natomiast jako program polityczny. W. Paruch wyróżnił koncepcje konsolidacji państwowej (1926-1935) i konsolidacji narodowej (1935-1939) Pierwsza zakładała akceptację dla mniejszości, które utożsamiały się z państwem polskim, druga, przeciwnie, prowadziła do ich wykluczenia ${ }^{5}$.

\section{CYGANIE PRZED 1926 ROKIEM}

Ponieważ spośród wybranych dzienników dwa („IKC” i „Polska Zbrojna”) wydawane były przed 1926 r., analizę problemu planowano rozpocząć, odnosząc się do narracji tych gazet na temat elity środowiska cygańskiego tuż po powstaniu państwowości polskiej, tym bardziej że dotychczas nie prowadzono badań nad tym okresem. Dzięki tej metodzie moż-

\section{......}

3 "Gazetę Polską" zaczęto wydawać od 1929 r. „Polska Zbrojna” wychodziła od 1919 r. jako półoficjalny organ prasowy Ministerstwa Spraw Wojskowych.

4 Wiesław Władyka podkreślił, iż "IKC", mimo oficjalnego zaangażowania w popieranie władzy, starał się przedstawiać swój profil jako bezpartyjny. Badacz ten zarazem silnie podkreślał sensacyjny charakter dziennika. Podobną opinię o "IKC" zawarł w swojej pracy Andrzej Paczkowski (1983). W nowszych badaniach akcentuje się, iż gazeta była największym opiniotwórczym dziennikiem informacyjnym. Zob.: Bańdo (2003, s. 266).

5 Szeroko na temat polityki narodowościowej w II RP pisał także Andrzej Chojnowski (1979). W publikacji tej brak jednak jakichkolwiek odniesień do kwestii cygańskiej. 
liwe byłoby prześledzenie ewentualnej zmiany sposobu opisu choćby bezimiennej elity cygańskiej lub samych Kwieków i porównanie tego wizerunku z tym występującym po zamachu majowym. Kwerenda nie wykazała jednak obecności w obu tytułach owego przedstawicielstwa, co pozwala łączyć jego pojawienie się z okresem późniejszym, gdy władzę w kraju sprawowała sanacja. Przeanalizowano zatem wizerunek samych Cyganów. W tej materii "IKC" sporządził o wiele więcej notatek niż „Polska Zbrojna”, co wiązało się ze wspomnianym znacznie większym rozmachem tego pierwszego. Pierwszą notatkę o ludności cygańskiej w „IKC” przedstawiono w 1920 r. na fali opisu zjawisk anarchizującego się kraju w związku z wojną polsko-bolszewicką, lecz nie wnosi ona nic ważnego do naszych rozważań, prezentując Cyganów jako ofiary wojennego czasú6. Drugą wzmiankę sporządzono dopiero w 1921 r. Przedstawiono w niej wewnętrzne rozgrywki środowiska cygańskiego, zauważając, iż nie jest ono grupą jednorodną tak pod względem narodowościowym, jak i organizacyjnym, dzielącą się na „partye”. Konstatacja powyższa, jakkolwiek krótka, jest o tyle istotna, iż świadczy o nie najgorszej ogólnej orientacji w wewnętrznej strukturze społeczności cygańskiej („Cygańskie oskarżenie cyganów”, 1921, s. 8, "IKC”, 1921, nr 212).

Kolejne relacje „IKC" w pierwszych latach po odzyskaniu przez Polskę niepodległości, przez okres następnych siedmiu lat w czasie, gdy u steru rządu znajdowała się centroprawica, również wskazywały na wewnętrzną różnorodność Cyganów, przy czym są to raczej luźne konstatacje, czynione niejako przy okazji opisywanych zdarzeń z udziałem Cyganów. Gros informacji dotyczył tarć i patologii w łonie tej zbiorowości. Stałym elementem był oczywiście wątek kryminalny. Pojawiały się doniesienia o mordach na współtowarzyszach, mordach przedstawicieli sił porządkowych i osób postronnych, porwaniach dzieci, napadach na pociągi, koniokradztwie, złodziejstwie, oszustwach, fałszywym wróżbiarstwie i czarach oraz fałszerstwie dokumentów?

Przestępstwa, jakich dopuszczali się Cyganie, spowodowały, że "IKC" wówczas potraktowat ich gremialnie jako element nie tyle obcy państwu, ile mu wrogi. Napływających w 1923, 1924 i 1925 r. Cyganów, między innymi do Krakowa, Torunia, Warszawy i Wawra, gdzie na rogatkach tych ośrodków rozbijali oni duże obozy, określit mianem „cygańskiej plagi”, „szumowin społecznych", roznoszących choroby, a nawet "szpiegów”8. $\mathrm{Na}$ ich negatywny obraz na łamach „IKC" złożyły się również doniesienia z procesu odbywającego się w 1927 r. w Słowacji, w którym sądzono przypadek kanibalizmu, jak podejrzewano, wśród tamtejszych Cyganów, pochodzących z miejscowości Szepsi lokolice

\section{......}

6 Dotyczyła ona napadu na tabor Cyganów węgierskich, obozujących w Żarkach (pow. częstochowski), którego dopuściła się okoliczna szajka bandytów („Napad bandycki na tabor cygański w Żarkach”, 1920, s. 6, "IKC", 1920, nr 126).

7 Zob.: "Straszna pomytka cygana-mordercy” (1922, s. 7, „IKC”, 1922, nr 74); "Cyganie-mordercy” (1922, s. 8, "IKC", 1922, nr 95); "Przyjazd cyganów rumuńskich do Krakowa” (1922, s. 7, "IKC”, 1922, nr 103); "Czarownicy przed sądem” (1922, s. 8, „IKC”, 1922, nr 157); "Ujęcie cygańskiej bandy zbójeckiej” (1922, s. 5, „IKC", 1922, nr 200); „Konie giną” (1924, s. 11, „IKC”, 1924, nr 225); "12-letnia dziewczynka porwana przez cyganów" (1924, s. 8, „IKC", 1924, nr 266); "Cygański wróżbita” (1924, s. 8, "IKC”, 1924, nr 293); „Mściwi cyganie” (1924, s. 7, „IKC”, 1924, nr 340); „Echa ekscesów antyżydowskich” (1926, s. 9, „IKC”, 1926, nr 245).

8 Zob.: "Inwazya cyganów na Polskę" (1923, s. 5, „IKC”, 1923, nr 171); "Niebywały skandal w Krakowie” (1924, s. 6, "IKC", 1924, nr 222); "Cygańska plaga” (1925, s. 8, "IKC”, "1925 nr 43). Modelowy przykład wrogiej Cyganom propagandy lansowanej w owym czasie przez "IKC" prezentował się następująco: "Na ulicach miasta zauważyć można wałęsające się grupki osobników, którzy swą zewnętrzną powierzchownością i wyglądem wybitnie różnią się od reszty przechodniów. Są to bolszewiccy cyganie, którzy jadą do Czech i zatrzymali się w Krakowie. (...) Ta ich wędrówka przypomina żywo owych Chińczyków z posążkami Buddy w ręku, którzy masowo, tuż przed wybuchem wojny zalali Kraków i Warszawę, a jak się później okazało, były to forpoczty szpiegowskie, nasłane przez Rosyę. Byłoby pożądane, aby nasze władze bliżej zajęły się owymi osobliwymi przybyszami”. Zob.: „Podejrzani goście w Krakowie” (1923, s. 8, „IKC”, 1923, nr 275). 
Koszyc) $)^{9}$. Katalog poruszanych spraw był więc, można rzec, "tradycyjny”, wpisujący się w schemat polskiej negatywnej narracji na temat Cyganów. Abstrahując od treści, zauważmy, iż za każdym niemal razem ludność ta prezentowana była jako masa, bezładnie i bez planu przemieszczająca się po terytorium państwa polskiego. Trasa ich przemarszu była zaś usiana czynami przestępczymi. Identyczne relacje pojawiały się w „Polsce Zbrojnej". Tu dodatkowo akcentowano wojowniczy charakter Cyganów i fakt, iż wchodzili oni w konflikty z siłami porządkowymi. Bez względu więc na sympatie polityczne obu gazet - wówczas chrześcijańskodemokratycznego "IKC”, związanego luźno z Polskim Stronnictwem Ludowym, i „Polski Zbrojnej” reprezentującej głos Ministerstwa Spraw Wojskowych, obraz Cyganów na ich stronicach był jednorodny i negatywny zarazem, sytuujący tę zbiorowość na marginesie życia społecznego ówczesnej Polski¹0.

\section{POJAWIENIE SIĘ CYGAŃSKIEJ REPREZENTACJI I PROMOCJA MICHAŁA ||}

Ten typ zapisu cygańskiej obecności na łamach dzienników uległ przeobrażeniu po 1926 r., gdy nowa władza sanacyjna przejęła w pełni kontrolę nad krajem. Nastąpiło wówczas zerwanie z wyłącznie jednostronnym, niesprzyjającym Cyganom konterfektem, a pojawił się nowy rodzaj opisu cygańskiego życia, wiążący się z aktywnością klanu Kwieków. Tym samym zagadnienie cygańskie przestało mieć depersonifikacyjny charakter. Zmiana narracji wynikała, jak można sądzić, z przyjęcia przez obóz rządowy niekonfrontacyjnej wobec mniejszości narodowych i etnicznych postawy, w przeciwieństwie do narodowej opozycji, co gwarantowała wspomniana koncepcja konsolidacji państwowej. Miała ona swoje źródło przede wszystkim w praktyce politycznej i administracyjnej - próba włączenia Cyganów na platformę sanacyjną była dla tego środowiska politycznego zapewne opłacalna. Aby stało się to możliwe, jak prawdopodobnie zakładano, potrzebna była reprezentacja społeczności cygańskiej, do czego idealnie nadawała się instytucja króla cygańskiego, reprezentowana przez Kwieków i mogąca dlatego stanowić swego rodzaju kanał komunikacyjny między władzą a Cyganami ${ }^{11}$.

"IKC" wprowadził nowy styl opisu w 1928 r. w ferworze przedwyborczego ożywienia. Wedle gazety aktywizacje polityczną przeżywało także środowisko Cyganów, które zgłosiło pomysł wystawienia własnej listy wyborczej, życzliwie ustosunkowanej do Bezpartyjnego Bloku Współpracy z Rządem (BBWR). Propozycja ta, jak podawano, została

\section{......}

9 Zob.: „Cyganie ludożercami?” (1927, s. 12, "IKC”, 1927, nr 62); "Cyganie-ludożercy” (1927, s. 6, "IKC”, 1927, nr 64); "Straszne szczegóły ludożerstwa uprawiane przez cyganów” (1927, s. 12, "IKC”, 1927, nr 65); "Mięso rudego dziecka przynosi szczęście” (1927, s. 10, "IKC”, 1927, nr 66); "Ludożercy z Mołdawji" (1927, s. 4, "IKC", 1927, nr 67); "Ludożercy z nad Wettawy” (1927, s. 4, "IKC”, 1927, nr 69); "Nowe zbrodnie ludożerców z Koszyc” (1927, s. 4, "IKC”, 1927, nr 70); "Dalsze szczegóły o ludożercach z Koszyc” (1927, s. 5, "IKC”, 1927, nr 71); "Nie znają Boga, nie boją się szatana” (1927, ss. 4-5, "IKC”, 1927, nr 74); "Kanibalizm cyganów z Mołdawy udowodniony" (1927, s. 5, „IKC”, 1927, nr 314).

10 Zob. na przykład: „Zbrodnia cyganów” (1923, s. 4, "Polska Zbrojna”, 1923, nr 102); "Krwawy dzień 1 maja w Ustrzykach" (1924, s. 9, „Polska Zbrojna”, 1924, nr 125); „Krwawy opór cyganów” (1924, s. 4, „Polska Zbrojna", 1924, nr 224). Jedna z notatek wskazuje natomiast na biedę wśród Cyganów. Opisano w niej, iż z głodu jeden z nich zamordował swego konkurenta, z którym rywalizował o dostęp do zakopanej w polu padliny końskiej (Nowosądeckie) („Końska padlina przyczyną morderstwa”, 1926, s. 7, „Polska Zbrojna”, 1926, nr 340).

11 Obóz rządowy w latach 1926-1935 do swojego programu przekonywał wszystkich przedstawicieli mniejszości narodowych i etnicznych, którzy zdolni byli zająć lojalistyczne stanowisko wobec państwa polskiego, przy czym sojusze taktyczne często miały nieoficjalny charakter, a czuwały nad nimi nie tyle elity rządowe, ile organa administracyjne. Klasycznym przykładem jest tu choćby „ciche" porozumienie BBWR z ortodoksją żydowską. Podobny nieformalny charakter miało zapewne zbliżenie do wybranej grupy Cyganów. Interesujące uwagi na temat polityki administracyjnej wobec mniejszości narodowych podał Waldemar Kozyra (2009). 
życzliwie przyjęta przez generalnego komisarza wyborczego. Przy tej okazji po raz pierwszy dokonano, nie bez pewnej rezerwy, szerszej prezentacji króla cygańskiego Jana Michalaka-Michalilescu. Na łamach „IKC" zabrał on głos, przedstawiając konkretne ambicje polityczne, które mogły się decydentom politycznym spodobać:

Jako motyw tego bądź co bądź ciekawego wystąpienia podał król cyganów, że cyganie w Polsce są upośledzeni i prześladowani, tak dalece, iż tylko ich właśni reprezentanci w izbach ustawodawczych mogą przeprowadzić uregulowanie spraw cygańskich. M.in. cyganie chcą przeprowadzenia reformy rolnej, aby osiąść już na stałe na ziemi i zacząć uczciwie pracować („Cygańska lista wyborcza”, 1928, s. 10, "IKC”, 1928, nr 13).

Akcją wyborczą wśród 12 tys. Cyganów, jak szacowała gazeta, mieli kierować „starostowie band cygańskich". Wydaje się zatem, iż moment wyborczy stał się punktem zwrotnym w dalszych relacjach Cyganów z władzą. Z pewnością BBWR był zainteresowany wówczas poparciem tej grupy i prawdopodobnie posłużył się nią tylko po to, aby poszerzyć bazę elektoratu, niemniej korzyści osiągnął także król, którego rozmowy z decydentami politycznymi legitymizowały, umacniając na pozycji królewskiej. Na pertraktacje te należy jednak przede wszystkim spojrzeć jako na rewolucyjny w dotychczasowej historii cygańskiej akt partycypacji w życiu publicznym, nawet jeśli Cyganie byli tylko przedmiotem rozgrywki politycznej, a wszystko mogło mieć posmak egzotyczny („Cygańska lista wyborcza", 1928, s. 10).

Kluczowa jest jednak kwestia, kto pierwszy w owym czasie - cygańskie przedstawicielstwo czy władza szukająca elektoratu - zdecydował się nawiązać kontakt. Odpowiedź na to pytanie przynajmniej częściowo niesie lektura „Polski Zbrojnej”, która wówczas przeistoczyła się w jeden z czołowych organów prasowych BBWR. Otóż w gazecie tej brak w ogóle informacji na temat jakiejkolwiek inicjatywy elit władzy w kierunku propagandowego wykorzystania zagadnienia cygańskiego. W czerwcu 1928 r. pojawiła się jedna zaledwie notatka dotycząca procesu sądowego „bandy cygańskiej” oskarżonej o zamordowanie trzech osób. Obojętność na działania Kwieków trwała do 1930 r. Tak więc wszystko wskazuje na to, że to klan z własnej inicjatywy zapragnął partycypować w życiu publicznym, zabierając głos $w$ imieniu swoim i grup, które reprezentowat, a prasa prorządowa („IKC"), a nie rządowa, umożliwiała tę artykulację. Świadczyć to może o tym, iż elita cygańska znacznie wcześniej mogła czynić próby zaistnienia, lecz była blokowana przez centroprawicowe rządy. Trzeba zarazem podkreślić, iż w latach 30. cygańscy reprezentanci coraz częściej starali się nawiązać kontakt z władzami, widząc w tym dobry i skuteczny sposób uwiarygodnienia się jako królowie. Tym samym, aczkolwiek podzieleni i rywalizujący ze sobą, w szybkim tempie rozpoczęli starania o zbudowanie przedstawicielstwa cygańskiego, mającego poparcie czy przychylność władzy ${ }^{12}$. Aktywizacja środowisk cygańskich miała zresztą miejsce w całej wschodniej Europie, np. w Rumunii powstał ruch na rzecz zjednoczenia wszystkich Cyganów (General Union of Romanian Roma) (Barany, 2002, ss. 100-103).

W obliczu konkurencji przychylność organów administracji stanowiła ważny argument w walce o wpływy. Czasem warunkowała w ogóle istnienie. Na przykład gdy w 1929 r. warszawskie władze metodami administracyjnymi starały się rozwiązywać tak zwany „problem cygański”, wydając nakaz "skasowania koczowisk cygańskich w obrębie Wielkiej Warszawy” („Król cyganów zagrożony”, 1929, s. 7, „IKC”, 1929, nr 178), pra-

\section{-.....}

12 Mord ten bulwersował społeczeństwo, ponieważ jego ofiarą padła rodzina nauczycielska z 3-letnim dzieckiem mieszkająca we wsi Proszkowo („Banda cygańska przed sądem”, 1928, s. 7, "Polska Zbrojna”, 1928, nr 307). 
sa napomknęła także o potrzebie likwidacji rezydencji królewskiej należącej do Bazylego Kwieka, znajdującej się na Marymoncie przy ul. Marii Kazimiery: „o ile więc król (...) zechce pozostać w stolicy, musi zwinąć namiot (...) i przenieść się do stałego mieszkania". Był to wyraźny sygnał, w jakim kierunku zmierza administracja, chcąc jak największą liczbę ludności cygańskiej włączyć w osadnictwo stałe. Hasło nawołujące Cyganów do osadnictwa stałego stawało się bowiem coraz częściej podnoszoną przez elity sanacyjne kwestią ${ }^{13}$.

Fakt, iż środowisko cygańskie było podzielone, został uszanowany przez sanację. Władze administracyjne nie zmierzały do wyłonienia koncesjonowanego cygańskiego przedstawicielstwa. Gdy w 1930 r. wybór króla cygańskiego padł na Michała Kwieka, "IKC" zdał relację z jego koronacji, odbytej w Piastowie pod Warszawą, gdzie "od dawien dawna [prawdopodobnie od czasów Królestwa Polskiego] stała osada cyganów” („Koronacja króla Michała II w Piastowie pod Warszawą”, 1925, s. 7, „IKC”, 1925, nr 25). Wraz z opisem samej koronacji dokonanej za pomocą "tombakowej korony, ozdobionej rzekomo cennemi klejnotami", dziennik silnie zaakcentował, iż podczas uroczystości był obecny przedstawiciel władz lokalnych - starosta powiatowy nazwiskiem Gajewski:

Starosta zwrócił się do króla (...) z krótką przemową, w której wyraził zadowolenie, że właśnie Kwiek, człowiek znany ze swojego statecznego usposobienia i rozumu, został wybrany królem. W odpowiedzi na to Kwiek, jako król Michał Il złożył uroczyste przyrzeczenie, iż wzorem przodków swoich, wierny pozostanie Polsce, jako krajowi, który plemieniu cygańskiemu okazuje gościnność ${ }^{14}$.

W kolejnych miesiącach 1930 r. stronice „IKC" zapełniały się życzliwymi notkami na temat działalności Michała II, wewnętrznego życia środowiska cygańskiego, lecz także rywalizacji pretendentów do tytułu króla. Michała przedstawiano jako rozjemcę w sprawach cygańskich i "gospodarza” Cyganów polskich oraz czechosłowackich, do których się udawał w celu rejestracji swoich zwolenników („Interwencja „króla cyganów” w policji poznańskiej”, 1930, s. 10, „IKC”, 1930, nr 105; "Król cygański Kwiek rejestruje swych poddanych w Czechosłowacji”, 1930, s. 13, „IKC”, 1930, nr 288). Wedle gazety najpoważniejszymi konkurentami Michała II byli wspomniany już Bazyli Kwiek i Jan Kwiek oraz w mniejszym stopniu Wasyl Kwiek ${ }^{15}$. Na fali tej rywalizacji „Gazeta Polska” pierwszy raz odniosła się do

\section{$\cdots \cdots \cdot$}

13 „Król cyganów zagrożony" (1929, s. 7). Posunięcia tego rodzaju nie były rozwijane w prasie sanacyjnej. Dwa tygodnie wcześniej w „Polsce Zbrojnej” pojawiła się następująca refleksja na temat podobnych czynów władz angielskich wobec tamtejszych Cyganów w czasie wyścigów konnych Derby w Epsom: „Nadprogramowym dodatkiem każdorocznych Derby stały się różnorodne widowiska w malowniczych taborach cyganów brytyjskich, którzy tydzień przed tym wielkim wydarzeniem zjeżdżali do Epsom z najdalszych zakątków Irlandii, Szkocji i Anglii (...) i otaczali barwnem obozowiskiem całe pole wyścigowe, wytwarzając harmider nie do opisania. W tym roku cyganów angielskich spotkała niemiła niespodzianka: wzmocnione oddziały policji oraz cała armia stewards czyli dozorców, nie dopuściła zbliżających się karawan na terytorium Epsom" („Listy z Anglii”, 1929, s. 4, „Polska Zbrojna”, 1929, nr 163). Zainteresowanie "Polski Zbrojnej” Cyganami w innych krajach zaowocowało także relacja z wizyty w Bułgarii, podczas której zwiedzano wioske cygańska przedstawiana jako wielką atrakcję ( "Z wędrówek po Bułgarii”, 1930, s. 10, "Polska Zbrojna”, 1930, nr 342). Zob. także: "Literatura cygańska” (1929, s. 7, „Polska Zbrojna”, 1929, nr 136).

14 Zaakcentowano również postać królowej Sedry-Lubiki, która "strój uroczysty przyozdobiła kilkoma kilogramami złotych dukatów, nanizanych na sznurki z końskiego włosia”. Zob.: „Koronacja króla Michała II w Piastowie pod Warszawą" (1925, s. 7).

15 "Bitwa cyganów w Mokotowie" (1930, s. 4, "IKC”, 1930, nr 159); "Walka o tron cygański w Poznaniu” (1930, s. 5, "IKC", 1930, nr 309); "Złodzieje Iwowscy czyhają na króla cyganów" (1931, s. 18, "IKC", 1931, nr 39); „Moskiewscy goście u cygańskiego króla Kwieka” (1931, s. 5, „IKC”, 1931, nr 43); „Rozprawa cygańska w sądzie łódzkim” (1931, s. 15, "IKC", 1931, nr 51). Postać Bazylego Kwieka prezentowano wówczas w negatywnym świetle, okraszonym posmakiem skandalu, opisując jego konflikty z synem Duda Kwiekiem, którego wydziedziczył. Syn z tego powodu próbował popełnić samobójstwo. Dotyczyło to również jego córki Marii, która także próbowała odebrać sobie życie, gdyż ojciec nie zezwolit jej na związanie się z „Cyganem nieszlachetnego urodzenia, którego królewna pokochała całym sercem”. Zob.: "Rewolucja pałacowa w rodzinie króla cyganów" (1930, s. 4, "IKC”, 1930, nr 317); "Tragedja w królewskiej rodzinie cyganów” (1930, s. 12, "IKC”, 1930, nr 332). 
reprezentacji cygańskiej, zamieszczając zdjęcie Bazylego Kwieka i jego rodziny z przychylnym podpisem: „Jego królewska mość król cygański Bazyli Kwiek po wzmocnieniu swojego stanowiska na zjeździe zadowolony z życia, zażywa wypoczynku w obozie na Marymoncie” („Jego królewska mość”, 1930, s. 6, "Gazeta Polska”, 1930, nr 217).

Najistotniejszym elementem promocji przedstawicielstwa cygańskiego był obszerny wywiad, jakiego udzielit Michał II "IKC", poprzedzony wstępem redaktorskim, odwołującym się do sielskich obrazków z życia Cyganów. Znalazło się również miejsce na charakterystykę wyglądu zewnętrznego króla, którego opisano jako bardzo przystojnego mężczyznę:

(...) w eleganckim, europejskim garniturze (...), autentyczny władca polskich cyganów. Tylko niepokojący egzotyczny profil oraz lekko opalona cera, świadczą o cygańskim pochodzeniu. Oczy, jak dwa węgle rozżarzone, połyskujące dziwnym ogniem, oraz uśmiech odsłaniający zdrowe, białe jak kreda, mocne zęby, przy falowaniu kruczych włosów, składają się na piękny typ wschodniej urody („Jego Królewska Mość Władca Cyganów w Krakowie”, 1930, s. 7, "IKC", 1930, nr 259).

„Europejski” król, posyłający córki i syna do polskiego gimnazjum, „nabywszy doświadczenia zagranicą w chwili, kiedy dzienniki rozniosły po świecie wiadomość, że Polska powstała wolna, jako obywatel polski, wrócił do kraju" - opisywał "IKC" jego życiorys, podkreślając, jak się zdaje, jego patriotyzm ( „Jego Królewska Mość Władca Cyganów w Krakowie”, 1930, s. 7). Następnie czytelnik mógł się dowiedzieć, że „zaczyna uwijać się wśród cyganów polskich, co przychodzi mu tym łatwiej, że ojciec jego Grzegorz piastował podówczas godność króla cyganów", lecz w 1930 r. (...) "złożył koronę z powodu podeszłego wieku” („Jego Królewska Mość Władca Cyganów w Krakowie”, 1930, s. 7). Centralnym punktem wywiadu była ekspozycja projektów mających na celu przeprowadzenie pewnego pakietu reform wśród Cyganów, co „IKC” skomentował jako zamierzenia ciekawe i rewolucyjne zarazem. Z pewnością podobały się one władzom, jeśli nie były wręcz z nimi konsultowane. Michał II postulował bowiem zachęcanie swoich braci do osiadłego trybu życia. W tym celu planował, aby Cyganie „mogli w sposób uczciwy pracować na chleb", zorganizować dla nich warsztaty, fabryki i osiedla robotnicze wraz z instytucjami oświatowymi i kulturalnymi. Szczegółowe plany zakładały utworzenie fabryki tkanin cygańskich w Sosnowcu, szkół powszechnych w Cieszynie i Sosnowcu oraz gimnazjum w Poznaniu. Placówki te miały być wzniesione z funduszy królewskich. Aby wizja ta wydawała się realna do spełnienia, podparto ją opisem wielkiego dworu królewskiego, jaki w Poznaniu posiadał Michał II:

W kamienicach znajdują się apartamenty oraz centrala administracji (...), urzęduje trybunał cygański złożony z trzech sędziów, prokuratora (...), areszt, (...) 5 wójtów, 5 policjantów cygańskich, oraz 4 sekretarzy, załatwiających korespondencję bieżącą ${ }^{16}$.

Król posiadał także letnie lub tymczasowe rezydencje, na przykład w Błogicy pod Cieszynem, a od 1931 r. w Wiśle czy w Zakopanem. Jak przedstawiano, grupa jego zwolenników sięgała około 14 tys. W podróżach po Polsce, zaczynających się często od wizyt u starostów i komisarzy policji, królowi towarzyszyli zaś „szef bezpieczeństwa” i kilku przybocznych gwardzistów. „IKC" prezentował tę postać, akcentując na koniec jej silną

16 „Jego Królewska Mość Władca Cyganów w Krakowie” (1930, s. 7). Instytucja dworu w II RP funkcjonowała także w tonie społeczności żydowskiej. Dwory chasydzkie prowadzone przez cadyków, zakładających dynastie, znajdowały się w wielu miastach i miasteczkach, na przykład w Górze Kalwarii - największym ośrodku chasydzkim oraz w Kocku, Nowomińsku, Parysowie, Skierniewicach etc. 
lojalność wobec państwa polskiego: „Na przyszłość (...) stosunki wśród cyganów poprawią się na lepsze i wszyscy będą pracować na odpowiednich stanowiskach, ku najpomyślniejszemu rozwojowi Polski, której obywatelami czują się wszyscy"17.

\section{PO WYBORACH BRZESKICH}

Po wyborach 1930 r., podczas których kwestia cygańska była półoficjalnie ponownie wykorzystywana przez sanację, w nowych warunkach politycznych "IKC" zerwał z przychylnym opisem osoby i działań Michała Kwieka, jednakowoż nie jest jasna przyczyna zmiany nastawienia. Powtórnie, podkreślmy, czołowa prasa sanacyjna nie lansowała otwarcie Cyganów na politycznych sojuszników kierowników życia politycznego, mimo że opozycja jej to przypisywała. Bez względu na te uwarunkowania, Kwiekowie pozostali jednak w centrum opisu świata cygańskiego ${ }^{18}$.

W 1931 r. prasa sanacyjna jawnie zabrała głos w kwestii cygańskiej. W „Gazecie Polskiej” Kwiekom poświęcono cykl dwóch obszernych artykułów zatytułowanych "Na marginesie cywilizacji". Pismo podało pobudki, dla których zajęło się tym tematem, co można odczytać jako próbę obrony ludności cygańskiej przed stereotypowymi wyobrażeniami o nich:

Nieco dziwaczne wieści, jakie przedostają się niekiedy do wiadomości publicznej o polskich cyganach wraz z atmosferą tajemniczości i zabobonu, jaką roztacza nad tym ludem „wieść gminna" i literatura, pobudzity nas do bezpośredniego wejrzenia w jego życie („Z wizytą w obozie polskich cyganów na Marymoncie: Rozmowa z Rudolfem Kwiekiem, prezesem Wielkiej Rady Cyganów”, 1931, s. 8, „Gazeta Polska”, 1931, nr 144).

Oba artykuły napisane zostały w sposób, który traktował liderów cygańskich z powagą i życzliwością zarazem. Na wstępie rozważań zaznaczono, iż Cyganie jako naród stanowili swego rodzaju fenomen z uwagi na ich wędrowny styl życia, który sprawiał kłopoty władzom ze względu na trudności „znalezienia im miejsca w ramach istniejącego ustroju prawnego". Najważniejszymi elementami prezentacji było przedstawienie struktury organizacyjnej tej mniejszości z Wielką Radą Cyganów Polskich (WRCP), na której czele stał kanclerz - Rudolf Kwiek i jako król Bazyli Kwiek. Wedle nich samych najwyżej postawioną osobą był Jonosz Kwiek, rezydujący w Londynie. Rozmówcy wskazali bowiem na dwustopniowy system organizacyjny - polski i krajowy. W Polsce WRCP tworzyli wójtowie (rajbaro), stojący na czele butrumów (taborów). Prócz tego działał sąd, składający się z 12 sędziów (krisbarı), zajmujący się sprawami cywilnymi: „kryminalne oddajemy sądom państwowym, bo jesteśmy lojalni wobec kraju, w którym mieszkamy". Kluczowymi kwestiami były także informacje na temat zamiarów polskiego króla, który wraz z innymi

17 W Poznaniu działała także fabryka kotłów zatrudniająca wyłącznie Cyganów w liczbie 550 osób. „Jego Królewska Mość Władca Cyganów w Krakowie" (1930, s. 7); "Jego Królewska Mość Król Kwiek w Sosnowcu” (1931, s. 5, "IKC", 1931, nr 17); "J.K.M. król Kwiek w Zakopanem" (1932, s. 12, "IKC”, 1932, nr 31). J. Ficowski (1985, s. 30) twierdzit, iż Michał II na polecenie władz dokonał spisu ludności cygańskiej, stąd pojawiła się liczba 14 tys. Cyganów. W rzeczywistości, wedle tego badacza, było ich dwa razy więcej, choć dokładnej liczby nie podawały żadne oficjalne dane państwowe.

18 Podczas wyborów różne środowiska powszechnie krytykowały alians władz z Cyganami. Jedna z socjalistycznych gazet napisała o postawie władzy: "Chwaliła się prasa sanacyjna, że wszyscy cygani w Polsce głosować będą na listę marszałka Piłsudskiego na czele z królem Kwiekiem". Jednocześnie wskazywała, iż związki sanacji z nimi były dla niej kompromitujące ze względu na rzekomą przestępczą naturę przedstawicieli zbiorowości cygańskiej („Sojusznicy sanacji”, 1931, s. 2, "Gazeta Robotnicza”, 1931, nr 23). Zob. także lewicowy głos chłopski w tej sprawie: „Król cygański” (1932, s. 11, „Zielony Sztandar”, 1932, nr 63). 
ośrodkami dążył do utworzenia siedziby narodowej oraz jego plany prowadzące do centralnej rejestracji Cyganów polskich, która miała być przeprowadzona za zgodą Komisarza Rządu na miasto Warszawę. Pierwsza z nich postrzegana była przez "Gazetę Polską" jako mrzonki i marzenia niemające szans na realizację. Ponownie uwagę przykuły także wnętrza królewskiej siedziby na Marymoncie, w której rezydował Bazyli:

Przy podmiejskiej uliczce stoją zwykłe domki parterowe, zamieszkane przez ludność polską. Trzeba przedostać się na tyły jednego z nich, tam w kotlince widzimy szereg drewnianych klitek i płóciennych szatr. Dwa największe domki zajmują: król Bazyli Kwiek oraz kanclerz bezpaństwowego narodu, prezes Wielkiej Rady Cygańskiej - Rudolf Kwiek. Król jest nieobecny w Warszawie - wyjechał na inspekcję. Mamy zamówioną audiencję u kanclerza. (...) Niska izba, zbudowanego z desek domku, ma w sobie coś z wnętrza koczowniczego, wschodniego namiotu. Pod ścianami leży pokotem na barwnych derkach i pierzynach liczna progenitura dostojnika, od maleńkiego drobiazgu aż do kilkunastoletnich dorodnych cór. Ściany zdobne w zawieszone wachlarzowo pocztówki, fotografie i portrety rodzinne. Na środku niziutki, okrągły stół, na którym małżonka Rudolfa Kwieka podejmuje nas herbatą i pączkami. Gospodarze oraz kilku cyganów zasiadają dokoła po turecku, dla nas przynoszą niziuteńkie stołeczki. Tu, w tych niepozornych szałasach na dalekich przedmieściach Warszawy, zbiegają się nici rządów wiążących kilkanaście tysięcy cyganów, rozproszonych po całej Polsce, tu jest jedna z filii władzy międzynarodowego cygaństwa (...) („Z wizytą w obozie polskich cyganów na Marymoncie: Rozmowa z Rudolfem Kwiekiem, prezesem Wielkiej Rady Cyganów, 1931, s. 8, "Gazeta Polska", 1931, nr 144; "Marzenia polskich cyganów o własnym państwie w Egipcie”, 1931, s. 8, "Gazeta Polska", 1931 nr 145).

Od momentu opublikowania wspomnianych dwóch artykułów w "Gazecie Polskiej" wytworzyła się ciepła atmosfera wokół Kwieków. Nawet zdystansowana dotąd od tematu cygańskiego „Polska Zbrojna” uznała za ważne, aby poinformować, iż nieznany szerzej członek tej rodziny, książę cygański, został ograbiony podczas podróży, wracając pociągiem z Mińska Mazowieckiego. Dzięki jego współpracy z policją udało się złapać złodzieja. W innych bardziej zaangażowanych relacjach przychylność prasy zyskiwał przede wszystkim Bazyli na niekorzyść Michała II. Ten ją tracił. Początkowo zajęto się występkiem jego bratanicy - Zofii Kwiekówny - która została aresztowana we Lwowie i postawiona przed sądem pod zarzutem kradzieży futra Abrahamowi Grendajerowi, u którego pojawiła się celem wróżenia. Na dotychczasowy "upudrowany” wizerunek tego króla jako „europejskiego społecznika" został więc rzucony cień związany z przewinieniami jego najbliższej rodziny. Król bowiem, chcąc bronić swojej bratanicy, jak donosił "IKC", pojawił się na jej rozprawie, oferując za nią kaucję „w dowolnej wysokości, nawet 10 tys. dolarów” („Bratanica króla cyganów przez sąd uniewinniona", 1931, s. 7, "IKC", 1931, nr 49). Wskazano też na niejasne interesy samego Michała II. Policja bowiem wykryła na jego dworze nielegalnie przebywające osoby greckiego pochodzenia, posługujące się fałszywymi paszportami ${ }^{19}$.

Wkrótce poinformowano o rywalizacji dwóch „dynastii cygańskich” (Michała II i Bazylego), co podważyło dotychczasową pozycję Michała. W maju 1931 r. „IKC” użył już wobec Michała II epitetu „samozwańczy król cygański”, naświetlając sposoby wzajemnej dyskredytacji zwalczających się obozów:

(...) Od dłuższego czasu trwają ciągłe niesnaski i walki. Władze sądowo-śledcze i policyjne zasypywane są najróżnorodniejszymi skargami, doniesieniami obu stron. Jedni na drugich rzucają najcięższe oskarżenia, donosząc o wszelkiego rodzaju wykroczeniach czy przestępstwach ("Walka dwóch dynastii cygańskich", 1931, s. 8, "IKC", 1931, nr 126).

\section{.....}

19 Osoby te przebywały w Warszawie w obozie cygańskim przy ul. Prądzyńskiego. Zob.: „Walka dwóch dynastii cygańskich (1931, s. 8 „IKC”, 1931, nr 126); "Okradzenie księcia cyganów” (1931, s. 8, „Polska Zbrojna", 1931, nr 228). 
Konflikt zaogniał się, gdyż Bazyli choć wydał manifest, w którym zrzekł się tytułu królewskiego, pozostawiając sobie funkcję wójta, to jednak nie zgodził się na przekazywanie pieniędzy do skarbca Michała II, pochodzących od swoich zwolenników („Walka dwóch dynastii cygańskich", 1931, s. 8).

"IKC", rozumiejąc wagę tej rywalizacji, informował o wielkiej mobilizacji dwóch dworów, których członkowie organizowali objazdy zgrupowań Cyganów w celach ewidencyjnych i podatkowych. Bazyli na przykład poprzez swojego wysłannika („adjutanta”), Pawła Kwieka, dokonywał w Łódzkiem w okolicach Bałut spisu poborowych cygańskich, co powodowało jednak sprzeciw samych Cyganów ${ }^{20}$. Także wyjazdy Michała II mającego o wiele szerszy krąg adherentów, znajdujących się również na terenie innych państw europejskich, spotykały się ze sprzeciwem - na przykład jego wizyta w Czechosłowacji, jak donoszono, zakończyła się wydaleniem go przez tamtejsze władze, odwiedziny zaś w Tarnowskich Górach zostały zakłócone wtargnięciem do namiotu króla przy ul. Nakielskiej i rabunkiem. Dopuścili się tego Cyganie pochodzący z powiatu stanistawowskiego ${ }^{21}$.

Podczas podróży Michała po Europie na łamach „IKC” pojawiła się natomiast krótka, przychylna notka o Bazylim, prezentująca go jako króla cygańskiego i „wielkiego przemystowca":

W tych dniach odbył się na polach piałkowskich pod Przemyślem wielki zjazd cyganów z całej Polski. Obrady toczyły się w języku cygańskim bardzo melodyjnym, trudnym jednak do zrozumienia dla niecygana. Na zakończenie pierwszego dnia obrad odbyła się w obozie cygańskim wielka zabawa, na której przed królem popisywali się w świetle pochodni i rozpalonych ognisk dorodni tancerze i tancerki, oraz doskonałe kapele cygańskie. Król (...) zatrzymał się w Przemyślu jeszcze na dni parę, ponieważ czyni on starania o uzyskanie dostaw do tamtejszego DOK. Król Bazyli (...) jest bowiem wielkim przemysłowcem i posiada od kilku lat w Poznaniu dużą fabrykę kotlarską, w której zatrudnia około 300 cyganów. Gtównym odbiorcą króla Bazylego jest wojsko zakupujące u niego kotty. Drugą fabrykę posiada król Bazyli pod Warszawą, wyrabiając w niej także i naczynia kuchenne („Król cyganów polskich - wielkim przemysłowcem”, 1932, s. 8, "IKC", 1932, nr 167).

Wzmocnienie pozytywnego przekazu na temat osoby Bazylego nastąpiło także dzięki przedstawianej wówczas dość tajemniczo postaci Mateusza (Matejasza) - „barona cygańskiego na Europę”, zwanego „królem Cyganów w Polsce”, który nagle i niespodziewanie pojawił się w Polsce. W krótkiej relacji z jego przyjazdu do kraju w maju 1932 r. poinformowano o tym, że zjawił się tu w celu nadzorowania naprawy kottów w inowrocławskich koszarach 59 pp. dokonywanych przez Cyganów-specjalistów. W sierpniu "IKC" zamieścit zaś obszerny z nim wywiad, w którym, występując niejako w imieniu Bazylego, podzielił się z czytelnikami zgoła inną wizją ułożenia stosunków wśród Cyganów. Główny przekaz polegał na pochwale dotychczasowego cygańskiego życia w Polsce, niewymagającego, zdaniem Matejasza, żadnych zmian i reform. Wszelkie patologie zaś, jakie stały się udziałem jego braci, tłumaczył on rozwarstwieniem społecznym:

20 Paweł Kwiek, nazywany przez "IKC” "wicekrólem”, został w 1932 r. aresztowany za "szereg oszustw na szkodę poddanych”, jakich dopuszczał się w Łódzkiem (Bałuty i Chojny). Zob.: „Aresztowanie adiutanta króla cyganów po krwawym asenterunku cygańskim" (1932, s. 9, "IKC", 1932, nr 109); "Uwięzienie wicekróla cygańskiego za oszustwo" (1932, s. 13, "IKC”, 1932, nr 177).

21 „Polski król cyganów wydalony z Czechosłowacji” (1932, s. 10, „IKC”, 1932, nr 148); „Poddani obrabowali cygańskiego króla” (1932, s. 13, „IKC”, 1932, nr 235); "Michał Kwiek, podróżny polski” (1932, s. 4, „IKC”, 1932, nr 261); "W Hamburgu bawi grupa polskich cyganów” (1932, s. 15, „IKC”, 1932, nr 272). Zob. także: "Napaść na króla cyganów" (1932, s. 7, „Polska Zbrojna", 1932, nr 233). 
Panowie muszą zrozumieć (...), że cyganie, jacy są w Polsce, dzielą się na pięć klas. Jeśli mowa o żebraninie, o złodziejstwie, to niech panowie wiedzą, że chodzi tu tylko o obozy czwartej i piątej klasy. Porządne obozy takiemi procederami się nie trudnią („Prawdziwy baron cygański”, 1932, ss. 2-3, „IKC”, 1932, nr 229).

Reszta Cyganów, w jego opinii, wiodła uczciwy żywot, trudniąc się kowalstwem i kotlarstwem, i wypełniała obowiązki obywatelskie wobec państwa polskiego. Również w powszechnym wśród Cyganek wróżbiarstwie, będącym nieraz źródłem oszustw, Matejasz dostrzegał zawód godny pochwały, twierdząc:

No tak, (...) bawią się. To też forma zarobkowania. Ale muszę powiedzieć, że są u cyganów kobiety, specjalnie dla wróżbiarstwa kształcone. Kształcą się w Jerozolimie. Niech się panowie nie śmieją (...) mogę przyprowadzić cygankę, która z ręki wyczyta każdemu z panów wszystkie, najtajniejsze nawet myśli. Pewnie nie każda cyganka, narzucająca się z wróżeniem, ma o wróżbiarstwie pojęcie. Ale są wróżki przygotowane do tego („Prawdziwy baron cygański”, 1932, s. 3).

Z wywiadu można było oprócz tego dowiedzieć się, że Cyganie byli członkami Kościoła grekokatolickiego. Matejasz podał też garść informacji z zakresu wewnętrznej struktury organizacyjnej tej grupy etnicznej oraz naświetlit rolę kobiety cygańskiej22. Spojrzenie to było krańcowo odmienne od tego, które prezentował Michał II. We wrześniu tego roku "IKC" przypomniał zresztą, opisując eskapady europejskie Michała, że objeżdża on obozy cygańskie, namawiając jego mieszkańców do porzucenia włóczęgostwa, żebraniny oraz wróżenia, co z pewnością aprobowały nie tylko polskie władze („Michał Kwiek, podróżny polski", 1932, s. 7, „IKC”, 1932, nr 261).

W kolejnym roku nie kontynuowano lansowania osoby króla Bazylego. Prawdopodobnie wpływ na to miał konflikt Matejasza z Bazylim o niejasnej genezie, lecz, jak się zdaje, przede wszystkim także fakt, że sanacyjny projekt, zmierzający do osiedlenia około 7 tys. Cyganów we wsi Bielsza w Krakowskiem, a także we wsiach pod Stanisławowem i pod Łodzią, koordynowany wspólnie z Matejaszem spalił na panewce, gdyż ten dopuścił się podobno korupcji na wielką skalę, żądając od Cyganów pieniędzy za ziemię, którą władze oddały Cyganom jakoby bezpłatnie. Jak możemy więc wnosić z tej krótkiej, aczkolwiek istotnej wzmianki prasowej, powodem, dla którego prasa zainteresowała się osobą Matejasza były jego bliżej nieznane porozumienia z organami administracyjnymi w celu przedsiębrania akcji osadniczej, korzystnej z punktu widzenia władz dla przynajmniej częściowego uporządkowania kwestii cygańskiej. Matejasz był więc kolejną osobą ze środowiska cygańskiego, która oddała się planom osadniczym („Walka o władzę w królewskim rodzie", 1932, s. 3, "Echo", 1932, nr 7).

$\mathrm{Na}$ fali zmagań głównych ośrodków cygańskich i tych mniej znaczących "IKC" w 1933 r. zapełnit się notatkami mającymi posmak sensacyjny, poświęconymi barwnemu życiu Kwieków noszących tytuł królewski lub, jak w przypadku Matejasza - barona. Głównie relacje pochodzity z najbardziej niespokojnego dworu Bazylego, lecz także nieznanego szerzej Iwana Kwieka. Pisano o wzajemnych napadach i rabunkach, nieszczęśliwych miłościach królewien, zdradach żon i innych skandalach obyczajowych, w których motywem przewodnim były porwania kobiet cygańskich przez zwaśnione rodziny²3. Prasa sanacyjna

22 Szwagier Matejasza, Latti Ganhar, zamężny z niejaką Oleną, był Persem. Zob.: „Cygańsko-perskie awantury" (1933, s. 12, "IKC", 1933, nr 210).

23 W marcu 1935 r. "dwór 'Bazylego, na który składały się trzy baraki, znajdujący się w Warszawie przy ul. Mińskiej, został dwukrotnie napadnięty przez nieznanych sprawców cygańskich, a budynki zniszczone. Rzekomo powodem wtargnięcia była chęć wykradzenia starożytnego skarbu królowej Saby. Miesiąc później król został zdetronizowany na zjeździe Cyganów, będących jego dotychczasowymi zwolennikami. Grupa ta opowiedzia- 
("Gazeta Polska” i „Polska Zbrojna”) szczególnie wnikliwie zajęła się natomiast sprawą rzekomego mordu 20-letniej Mani Kwiek, kuzynki Bazylego, która wyrokiem sądu cygańskiego miała zostać zamordowana za niewierność małżeńską. Samosąd gazety nazwały "zbrodnią" tej instytucji. Od tego czasu postać Bazylego zniknęła z kart pism rządowych i prorządowych („Zbrodnia cygańskiego sądu”, 1933, s. 10, "Gazeta Polska”, 1933, nr 13; "Tajemnica zniknięcia cygańskiej Messaliny”, 1933, s. 7, „Polska Zbrojna”, 1933, nr 13; „Poszukiwania Mani Kwiek”, 1933, s. 7, „Polska Zbrojna”, 1933, nr 14; "Mania Kwiek znalazła się", 1933, s. 8, „Polska Zbrojna”, 1933, nr 19).

\section{W STRONĘ REFORM - MICHAL I MATEJASZ}

Konflikty powstałe na tym tle, jak i inne ostatecznie doprowadzity do wzajemnego rozliczania. Powstał nawet szerszy ruch zmierzający do odseparowania się Kwieków pochodzących ze szlachetnego rodu, od tych, którzy nosili to nazwisko, aczkolwiek nie należeli do elity. Akcją tą kierował, jak podawał "IKC", Matejasz Kwiek, który na łamach dziennika zachęcał do zgłaszania się do niego z rodzinnymi dokumentami, aby poświadczyć owe szlachectwo:

Za dużo jest wśród cyganów w Polsce rodzin noszących nasze nazwisko rodowe. Nie ulega wątpliwości, że wiele z tych rodzin zalicza się do naszego rodu niesłusznie. Nasz ród jest starym rodem cygańskim. Stanowi on u cyganów arystokrację. (...) Ród musi dbać o siebie ${ }^{24}$.

Od pewnego momentu "IKC" zaczął opisywać wewnętrzne sprawy cygańskie z perspektywy dwóch postaci - Michała II i Matejasza Kwieka, nie unikając akcentowania barwności świata cygańskiego, co też wynikało z zachowania cygańskich reprezentantów i używania przez nich wszelkich atrybutów charakterystycznych dla tej grupy etnicznej. Obaj, jak wynika z relacji prasowych, byli jednak lojalnie ustosunkowani do rządu sanacyjnego i zarazem, rywalizując ze sobą, rzeczywiście wyróżniali się elokwencją oraz znacznymi wpływami w stosunku do reszty reprezentantów klanu Kwieków nie tylko w Polsce, ale i w innych krajach europejskich. Nie zabrakło więc doniesień na temat tak dalekosiężnych projektów Michała II jak jego inicjatywa zamierzająca do utworzenia państwa cygańskiego „na jednej z wysp afrykańskich” („Król cygański Kwiek zakłada państwo w Afryce", 1934, s. 10, „IKC", 1934, nr 43). W tym celu złożył on wizytę w Londynie, gdzie zwrócił się do tamtejszego rządu z prośbą o prawo osiedlenia się 15 tys. Cyganów w Afryce. Przekazał też mu petycję w tej sprawie z podpisami kilku tysięcy rodaków, wygłaszając przedtem mowę w Hyde Parku. Kwiek brał także pod uwagę założenie państwa cygańskiego w Azji nad Gangesem, do której to ziemi, jak argumentował na

\section{......}

ła się za Matejaszem. Odpływ adherentów spowodował, iż Bazyli utracit źródła dochodu i wkrótce otrzymał wyrok egzekucyjny nakazujący opuścić zajmowane mieszkania. Komornik dokonał także zajęcia ruchomości, które zostały sprzedane na licytacji. ( "Syn króla cyganów uniewinniony od zarzutu napadu”, 1933, s. 12, "IKC", 1933, nr 9; „Kobietę, która zdradza męża, każe się śmiercią", 1933, s. 11, "IKC", 1933, nr 14; „Gdzie zaginęła cyganka z królewskiego rodu”, 1933, s. 8, "IKC”, 1933, nr 19; "Bratanica króla cyganów popełniła zamach samobójczy”, 1933, s. 12, "IKC”, 1933, nr 188; "Napad bandytów na króla cyganów”, 1933, s. 7 , "IKC", 1933, nr 201; "Cygańsko-perskie awantury", 1933, s. 12; „Uprowadzenie królewny", 1933, s. 14, "IKC", 1933, nr 315; "Walka cyganów o skarb królowej Saby", 1935, s. 10, "IKC", 1935, nr 89; „Komornik i licytacja u zdetronizowanego króla", 1935, s. 11, "IKC", 1935, nr 103).

24 "Prawdziwy baron cygański" (1932, s. 3). Nazwisko Kwiek wybierało sobie także wielu Cyganów-obcokrajowców, nielegalnie przebywających w Polsce, zasilających często półświatek przestępczy. Na temat krakowskich demaskacji takich grup cygańskich pochodzących z Jugosławii i Grecji zob.: "Baron cygański w Krakowie wyławia fałszywe paszporty" (1933, s. 18, „IKC", 1933, nr 99). 
łamach „IKC”, „mamy zresztą historyczne prawo”. Z pewnością nikt w Polsce do projektów tych nie przykładał wagi, jednakowoż warto podkreślić, iż to właśnie klan Kwieków podnosit tego typu kwestie dotyczące przecież całokształtu organizacji społeczności cygańskiej. Szukając wytłumaczenia dla pojawienia się tego typu pomysłów, nasuwa się analogia do postulatów środowisk żydowskich, które zmierzały do stworzenia swego państwa. Przypomnijmy, iż w latach 30. część Żydów wspólnie z rządem polskim nowej ojczyzny poszukiwała nawet na niegościnnej wyspie Madagaskar. Niebagatelne znaczenie dla podniesienia tej kwestii miał także wzrost nacjonalizmów w Europie w latach 30. ( "Król cyganów Michał II Kwiek z Poznania w Rumunji”, 1934, s. 4, "IKC”, 1934, nr 291; "Król cyganów Michał Kwiek prosi o ziemię w Afryce”, 1934, s. 6, „IKC”, 1934, nr 309).

Szukając legitymizacji, Michał II Kwiek w kwietniu 1934 r. oficjalnie za pośrednictwem prasy zwrócił się do władz o poparcie jego osoby w rywalizacji z poważnym adwersarzem, na jakiego wyrósł Mikita Kościniak z Sosnowca („Walka cyganów w komisariacie policji i szambelan w pyjamie”, 1934, s. 13, "IKC", 1934, nr 111). Następnie Michał dokonał oficjalnej koronacji w czerwcu 1934 r. w Wielkich Hajdukach ${ }^{25}$ (powiat chorzowski) na króla Cyganów, wykorzystując jako pretekst do tego posunięcia wesele swego syna. Jak donosiła prasa, stało się tak, gdyż nigdy wcześniej nie zorganizował on oficjalnej ceremonii koronacji, a był tylko „zwyczajnym królem”, obwołanym przez zgromadzonych Cyganów. Od tego czasu zaczął nosić tytulature "Kwiek rex" i stał się „jedynym królem Cyganów”. Koronacja odbyła się przy udziale wielu gości z zagranicy, m.in. królów z Barcelony, Rio de Janeiro i Buenos Aires, czego nie omieszkał nie zauważyć "IKC" ("Zjazd cyganów z całego świata na wesele następcy tronu króla Kwieka, 1934, s. 8, „IKC”, 1934, nr 153). Jak przekazywał dziennik, w ramach kampanii wyborczej Michał obiecał zniesienie podatku od wierzchowców, pobieranego przez niego od Cyganów, oraz zmianę wewnętrznej konstytucji regulującej życie cygańskie w Polsce, idącą w kierunku demokratyzacji. Zanim nastąpiła koronacja, Michał zdławił wewnętrzną opozycję. Kontrkandydaci, bracia Gustaw i Wasyl Kwiekowie, nie posiadali zresztą znaczących wpływów, a ich aktywność przedwyborcza ograniczała się do obstrukcji elekcji (odbywającej się co pięć lat), polegającej na ich trzykrotnej absencji. Metoda ta mogła skutkować tylko trzy razy, gdyż jak podawał "IKC", wedle konstytucji cygańskiej, „w czwartym terminie wybory muszą się odbyć, choćby się zjawił na elekcji tylko jeden kandydat”. Nie stanowili oni więc realnego zagrożenia ( „Jego Królewska Mość Michał Kwiek", 1934, s. 7, "IKC”, 1934, nr 302).

Po koronacji, w październiku na czwartej, prestiżowej stronie "IKC" pojawił się wywiad z Michatem II. Ponownie, jak miało to miejsce w latach poprzednich, dokonano jego prezentacji jako osoby cechującej się europejskim sznytem: uczestnika kongresu cygańskiego w Radowcach (Bukowina rumuńska), wizytatora polskiego konsulatu w Czerniowcach, osobę władającą kilkoma językami, twórcę i propagatora szkół powszechnych w Poznaniu i Bukareszcie, przemysłowca, a co najistotniejsze - dysponenta zezwoleń władz polskich na odbycie elekcji. Podczas wywiadu padła ważna deklaracja. Otóż król nie zamierzał „tworzyć w Polsce cygańskiej mniejszości narodowej”, lecz pragnął doprowadzić do założenia państwa cygańskiego w Azji nad Gangesem. Projekty te nie miały z pewnością realnego poparcia władz, ale były na tyle nieszkodliwe, że pozwalano je jako ciekawostkę wygłaszać publicznie („KKól cyganów Michał II Kwiek z Poznania w Rumunji”, 1934, s. 4). Bardziej przyziemny program zakładał natomiast walkę ze zjawiskiem przestępczości wśród Cyganów wspólnie z policją polską, przy pomocy własnej policji śledczej i cygańskiego sądownictwa ( "Król cyganów Kwiek ofiarował pomoc policji stanisławowskiej",

-.・・

25 Obecnie Chorzów Batory. 
1935, s. 14, "IKC”, 1935, nr 6; "Sędziowie króla Kwieka, którzy chcą pić za darmo”, 1935, s. 9, „IKC”, 1935, nr 39).

Jak wspomniano, równolegle z promocją osoby Michała, W "IKC" następowała prezentacja działań Matejasza Kwieka. W lutym 1935 r. dziennik z zaciekawieniem poinformowat, że na międzynarodowym zjeździe Cyganów w 1934 r. zrezygnował on z piastowania funkcji króla, gdyż

władza monarsza w Polsce nie istnieje. Toteż na zjeździe w Warszawie wystosował orędzie do swoich poddanych, w którem zrzeka się tytułu króla, jako podlegający wraz z całem plemieniem cygańskim rządowi Rzplitej polskiej, i odtąd zapowiada, że będzie nosił tylko tytuł Wodza Narodu Cygańskiego („Wódz narodu cygańskiego”, 1935, s. 10, "IKC”, 1935, nr 45; "Komornik i licytacja u zdetronizowanego króla", 1935, s. 11, "IKC", 1935, nr 103).

W tym samym miesiącu, w krótkim wywiadzie, Matejasz zapowiedział, że „każdego cygana, który by się mianował królem, uważać będziemy za samozwańca" i dodawał:

Planuję wiele reform. W pierwszym rzędzie chciałbym podnieść poziom życia moralnego cyganów i doprowadzić do tego, żeby bracia moi większym się cieszyli wszędzie szacunkiem i zaufaniem. Bezwzględną walkę wypowiadam oszustom, szarlatanom i złodziejom („Program wodza narodu cygańskiego", 1935, s. 7, "IKC", 1935, nr 52).

Złożył przy tym wyraźną deklarację lojalności wobec państwa polskiego. Stronie polskiej zapewne spodobała się nowa instytucja władzy cygańskiej. Skasowanie dotychczasowego tytułu królewskiego było z pewnością związane z duchem czasów, w których coraz częściej opierano się na silnym przywództwie - wodzu, tym bardziej że pomysł ten stanowił otwarte nawiązanie do postaci Józefa Piłsudskiego. Również deklarowany program walki z przestępczością wśród Cyganów, stanowiącą poważny problem, okazywał się atrakcyjny, zwłaszcza że Michał II nie cieszył się przecież uznaniem wszystkich Cyganów. W ten sposób "IKC" stawał się tubą propagandową określonych postulatów reform cygańskiej mniejszości, lansującą jednocześnie dwa przeciwstawne sobie obozy cygańskie ${ }^{26}$.

Odrębną sprawą jest kwestia wiarygodności pomystów przywódców cygańskich. Wspomnieliśmy już o projektach utworzenia państwa cygańskiego. Nie istnieją źródła, które mogłyby naświetlić to, czy sami liderzy traktowali temat ten poważnie, czy też raczej wykorzystywali go w celach propagandowych. Trudno w ogóle odnosić się to tych zagadnień, ponieważ brak danych na temat kwestii wdrażania przedstawianych programów („Program wodza narodu cygańskiego”, 1935, s. 7). Niewątpliwie natomiast liderzy cygańscy zdawali sobie sprawę, że sprawy kryminalnych występków Cyganów należały do kwestii pierwszoplanowych z punktu widzenia władz państwowych. Stąd te decydowały się popierać każdego, kto ze zjawiskiem przestępczości walczył. W marcu 1935 r. na przykład pojawił się W "IKC" artykut, który nakreślał energiczne działania Józefa Kwieka ${ }^{27}$, prezesa rady Cyganów ${ }^{28}$, będącego stronnikiem Matejasza, którego celem była eli-

$\cdots \cdot \cdot$

"Program wodza narodu cygańskiego" (1935, s. 7). Hasło zniesienia instytucji królewskiej tuż po śmierci J. Piłsudskiego przestało obowiązywać. Stronnik Matejasza w 1935 r. - Józef Kwiek nawoływał wówczas wśród swoich zwolenników do wznowienia uprzednio zarzuconej tradycji obierania króla. W tym celu jego obóz w listopadzie 1935 r. zwołał kilkutysięczny zjazd Cyganów do Żabiego (powiat kosowski, Huculszczyzna). Zob.: „Cyganie wybierają swojego króla” (1935, s. 14, „IKC”, 1935, nr 311).

27 Józef Kwiek został obrany przez Cyganów królem w 1934 r. w Katowicach na Zaciszu na okres 8 lat. We Lwowie prowadzit sklep pod nazwą „Chrześcijańska Mleczarnia Higieniczna”. Specjalnością zakładu były m.in. kiełbasy rumuńskie. W 1935 r. prowadził intensywną kampanię na rzecz utworzenia państwa cygańskiego w Afryce („Król mleczarzem”, 1935, s. 6, "IKC”, 1935, nr 209; "Cyganie wybierają swojego króla”, 1935, s. 14).

28 Prawdopodobnie chodzi o utworzoną w 1935 r., w Czerniowcach podczas międzynarodowego kongresu cygańskiego z udziałem przedstawicieli 9 państw europejskich, Stanów Zjednoczonych oraz reprezentantów 
minacja zjawiska przestępczości kryminalnej - „wyłapuje złodziei, oczyszcza atmosfere wśród cyganów, złodziei oddaje władzom" - pisano W "IKC"29. W opinii Józefa Kwieka najgroźniejszym jednak przestępcą w łonie społeczności cygańskiej był Michał II, gdyż stał za wieloma kradzieżami, organizowanymi na terenie kraju oraz próbował wpajać Cyganom ideologię komunistyczną, dlatego nawoływał, aby "specjalnie ścigać samozwańca”. Tego rodzaju retoryka świadczy o tym, iż kierownicy życia cygańskiego doskonale zdawali sobie sprawę z tego, które hasła oraz jakiego typu oskarżenia pobudzały społeczeństwo większościowe do reakcji. Trudno bowiem twierdzić, iż oskarżenia Michała II o komunizm lub jego rzekome poparcie dla kradzieży Józef Kwiek kierował do mas cygańskich. Wewnątrz zbiorowości cygańskiej stosowano innego rodzaju slogany. Wspomniano na przykład o obietnicy zniesienia podatku od wierzchowców, demokratyzacji czy zapowiedziach utrzymania w pewnych sferach życia cygańskiego statusu quo („Silna ręka wodza cyganów", 1935, s. 4).

Niewątpliwie główne punkty programów dwóch zwalczających się ośrodków, na czele których stali Kwiekowie, były do siebie, w świetle relacji "IKC", niemal bliźniaczo podobne. W pierwszej kolejności należało złożyć zapewnienie o lojalności wobec państwa polskiego, następnie liczyła się walka z przestępczością oraz projekty kolonizacyjne zmierzające do trwałego osadzenia przynajmniej części Cyganów na wyznaczonych im obszarach. Zdaje się, iż swoiście cygańskim projektem z grupy tych wielkich zamierzeń, pozbawionym inspiracji czynników rządowych, były plany utworzenia państwa cygańskiego. Obóz Matejasza snuł projekty zorganizowania go nie tylko w Afryce przy wsparciu Ligi Narodów, jak chciał Michał II, lecz także na Polesiu, co oznaczało poparcie przynajmniej nominalne dla planu likwidacji koczowniczego trybu życia. Podstawową natomiast różnice między dwiema siłami, jak informował „IKC", stanowiły zapędy reformatorskie Michała II. Chciał on Cyganów asymilować i europeizować oraz wprowadzić do ich życia szkolnictwo powszechne, o czym już wspomniano. Prawdopodobnie, mając na względzie szanse realizacji powyższych planów, należałoby potraktować je w kategoriach mrzonek, aczkolwiek nie jest właściwym bagatelizowanie ich. Bez względu bowiem na powodzenie realizacji wskazanych przedsięwzięć, jak i rzeczywiste intencje samych liderów, postulaty te są jednocześnie zapisem działania, sposobu myślenia i w ogóle mentalności ówczesnej elity cygańskiej, która niemal przebojem wdarła się na arenę życia publicznego i częściowo politycznego („Silna ręka wodza cyganów”, 1935, s. 5).

Śmierć J. Piłsudskiego w 1935 r. zamknęła pewien okres w dziejach państwa polskiego. Także Kwiekowie wzięli udział w pożegnaniu Wodza. Przodował w tym obóz Matejasza, który zarządził sześciotygodniową żałobę mającą obowiązywać we wszystkich taborach cygańskich, a zabraniającą koncertowania, skocznych zabaw oraz zawierania w tym czasie małżeństw i organizowania wesel („W żałobie narodowej biorą udział cyganie”, 1935, s. 17, „IKC”, 1935, nr 135).

\section{.....}

Ameryki Południowej, Światową Unię Cyganów. Jej celem była szersza dyskusja na temat „obrony interesów Cyganów, spraw obywatelstwa i spraw paszportowych" („Międzynarodowa unja cyganów”, 1935, s. 9, "IKC", 1935, nr 24)

29 Cyganów oddawano również pod sąd cygański. Przestępstwa mniejszego kalibru karano chłostą do 25 kijów, za cięższe golono wąsy i włosy na głowie, w sposób symboliczny wykluczając osoby te ze społeczności. Jak donosit "IKC", „ta druga [kara] jest bardzo bolesna i równa się karze śmierci" ( Silna ręka wodza cyganów”, 1935, s. 4, "IKC”, 1935, nr 64). 
"IKC" był tym forum prasowym, które zapoczątkowało promocję klanu Kwieków na przywódców cygańskiej mniejszości etnicznej. Ta organizacja klanowa oraz Cyganie, jako mniejszość etniczna, zostali włączeni tym samym w ramy koncepcji konsolidacji państwowej. Sposób relacjonowania tego tematu wskazuje, że elity sanacyjne traktowały tych liderów z uwagą i zainteresowaniem, biorąc poprawkę na specyfikę zachowania i uznawany za folklorystyczny styl przywódców cygańskich. Gazety informowały ponadto (głównie "IKC") o tym, iż Kwiekowie, będąc jedynymi właściwie przedstawicielami elity cygańskiej, stali się w całej pełni partnerami dialogu z władzami, a nawet przejawiali ambicje polityczne. Prezentowali też skonkretyzowane plany wobec całokształtu życia cygańskiego w Polsce, mające dla Cyganów doniosłe znaczenie, choć działania te z pewnością nie były pozbawione inspiracji ze strony czynników państwowych i administracyjnych. Fundamentalną kwestią była zawsze deklaracja lojalności wobec państwa. Silna klanowa rywalizacja o zaszczyty i splendor, wynikający z podziałów w obrębie cygańskiej zbiorowości, uniemożliwiały sanacji długotrwałe lansowanie jednego kandydata. Nie było zresztą takiej potrzeby. Zamiast tego, mając na względzie duże podziały w klanie, przychylnie patrzono na każdego, kto wykazywał chęć rozwiązywania licznych problemów, które trapiły skupiska cygańskie w Polsce. W efekcie uznać można, iż Kwiekom udało się zbudować dobre relacje z elitami sanacyjnymi, choć nie brakowało w nich obustronnego, instrumentalnego traktowania pewnych zagadnień. Był to w zasadzie pewien nieformalny układ czy też porozumienie, z którego korzystały dwie strony - Kwiekowie, jako liderzy cygańscy, oraz państwo, które miało za sobą szersze grupy cygańskie. W ten sposób obie siły kontrolowały razem i trzymały w ryzach społeczność cygańską mimo pewnej iluzoryczności tego nadzoru spowodowanej koczowniczym trybem życia Cyganów. Działanie to miało zarówno pozytywne, jak i negatywne skutki dla ogółu ludności cygańskiej. Trzeba także przyznać, iż ówczesne czynniki polityczne traktowały mimo wszystko sprawy związane ze społecznością cygańską jako zagadnienie marginalne.

\section{PRASA}

"Echo", 1932, nr 7.

"Gazeta Polska”, 1930, nr 217; 1931, nr 144, nr 145; 1933, nr 13.

"Gazeta Robotnicza”, 1931, nr 23.

"Ilustrowany Kuryer Codzienny", 1921, nr 212; 1922, nr 74, nr 95, nr 103, nr 157, nr 200; 1923, nr 171, nr 275; 1924, nr 222, nr 225, nr 266, nr 293, nr 340; 1925, nr 25, nr 43; 1926, nr 245; 1927, nr 62, nr 64, nr 65, nr 66, nr 67, nr 69, nr 70, nr 71, nr 74, nr 314; 1928, nr 13; 1929, nr 178; 1930, nr 105, nr 159, nr 259, nr 288, nr 309, nr 317, nr 332; 1931, nr 17, nr 39, nr 43, nr 49, nr 51, nr 126; 1932, nr 31, nr 109, nr 148, nr 167, nr 177, nr 229, nr 235, nr 261, nr 272; 1933, nr 9, nr 14, nr 19, nr 99, nr 188, nr 201, nr 210, nr 315; 1934, nr 43, nr 111, nr 153, nr 291, nr 302, nr 309; 1935, nr 6, nr 24, nr 39, nr 45, nr 52, nr 64, nr 89, nr 103, nr 135, nr 209, nr 311.

„Polska Zbrojna", 1923, nr 102; 1924, nr 125, nr 224; 1926, nr 340; 1928, nr 307; 1929, nr 136, nr 163; 1931, nr 228; 1932, nr 233; 1933, nr 13, nr 14, nr 19.

"Zielony Sztandar", 1932, nr 63. 
Bańdo, A. (2003). „Ilustrowany Kurier Codzienny” w dziewięćdziesiątą rocznice powstania (1910-2000). Annales Academiae Paedagogicae Cracoviensis: Studia ad Bibliothecarum Scientiam Pertinentia, 2, 119-144.

Barany, Z. (2002). The East European Gypsies: Regime change, marginality and ethnopolitics. Cambridge: Cambridge University Press.

Borowiec, P. (2005). Jesteśmy głosem milionów: Dzieje krakowskiego wydawnictwa i koncernu prasowego Ilustrowany Kurier Codzienny (1910-1939). Kraków: Wydawnictwo Uniwersytetu Jagiellońskiego.

Chojnowski, A. (1979. Koncepcje polityki narodowościowej rządów polskich w latach 1921-1939. Wrocław: Zakład Narodowy im. Ossolińskich.

Ficowski, J. (1985). Cyganie na polskich drogach. Kraków: Wydawnictwo Literackie.

Gontarek, A. (w druku). Obraz Cyganów na łamach prasy narodowej w latach 1935-1939 (na przykładzie „Warszawskiego Dziennika Narodowego"). Studia Historica Gedanensia, 9.

Kozyra, W. (2009). Polityka administracyjna ministrów spraw wewnętrznych Rzeczypospolitej Polskiej 1918-1939. Lublin: Wydawnictwo Uniwersytetu Marii Curie-Skłodowskiej.

Mirga, A. (1998). Proces kształtowania się podmiotowości politycznej. W P. Madajczyk (Red.), Mniejszości narodowe w Polsce: Państwo i spoteczeństwo a mniejszości narodowe w okresach przełomów politycznych (1944-1989). Warszawa: Instytut Studiów Politycznych PAN.

Paczkowski, A. (1983). Prasa codzienna Warszawy w latach 1918-1939. Warszawa: Państwowy Instytut Wydawniczy.

Paruch, W. (2001). Od konsolidacji państwowej do konsolidacji narodowej: Obóz piłsudczykowski (1926-1939). W J. Jachymek \& W. Paruch (Red.), Między rzeczywistością polityczną a światem iluzji: rozwiązania problemu mniejszości narodowych w polskiej myśli politycznej XX wieku (ss. 71-118). Lublin: Wydawnictwo Uniwersytetu Marii Curie-Skłodowskiej.

Seniów, J. (1998). Oblicze ideowe i funkcja „Gazety Polskiej” (1929-1939). Rocznik Historii Prasy Polskiej, 1(1-2), 49-67.

Władyka, W. (1979). Polityczne oblicze prasy ogólnoinformacyjnej w Drugiej Rzeczypospolitej. Kwartalnik Historii Prasy Polskiej, 18(4), 87-101.

PRASA

\section{Echo}

Walka o władzę w królewskim rodzie. (1932, styczeń 7). Echo, s. 3.

Gazeta Polska

Jego królewska mość. (1930, sierpień). Gazeta Polska, 1930(217), s. 6.

Z wizytą w obozie polskich cyganów na Marymoncie: Rozmowa z Rudolfem Kwiekiem

prezesem Wielkiej Rady Cyganów. (1931, maj). Gazeta Polska, 1931(144), s. 8.

Marzenia polskich cyganów o własnym państwie w Egipcie. (1931, maj). Gazeta Polska, 1931(145), s. 8.

Zbrodnia cygańskiego sądu. (1933, styczeń). Gazeta Polska, 1933(13), s. 10. 


\section{Gazeta Robotnicza}

Sojusznicy sanacji. (1931, styczeń 29). Gazeta Robotnicza, s. 2.

\section{Ilustrowany Kuryer Codzienny}

Napad bandycki na tabor cygański w Żarkach. (1920, maj 9). Ilustrowany Kuryer Codzienny, s. 6.

Cygańskie oskarżenie cyganów. (1921, sierpień 7). Ilustrowany Kuryer Codzienny, s. 8.

Straszna pomytka cygana-mordercy. (1922, marzec 15). Ilustrowany Kuryer Codzienny, s. 7. Cyganie-mordercy. (1922, kwiecień 6). Ilustrowany Kuryer Codzienny, s. 8.

Przyjazd cyganów rumuńskich do Krakowa. (1922, kwiecień 14). Ilustrowany Kuryer Codzienny, s. 7.

Czarownicy przed sądem. (1922, czerwiec 14). Ilustrowany Kuryer Codzienny, s. 8.

Ujęcie cygańskiej bandy zbójeckiej. (1922, lipiec 27). Ilustrowany Kuryer Codzienny, s. 5.

Inwazya cyganów na Polskę. (1923, lipiec 19). Ilustrowany Kuryer Codzienny, s. 5.

Podejrzani goście w Krakowie. (1923, listopad 2). Ilustrowany Kuryer Codzienny, s. 8.

Niebywały skandal w Krakowie. (1924, sierpień 15). Ilustrowany Kuryer Codzienny, s. 6.

Konie giną. (1924, sierpień 18). Ilustrowany Kuryer Codzienny, s. 11.

12-letnia dziewczynka porwana przez cyganów. (1924, wrzesień 29). Ilustrowany Kuryer Codzienny, s. 8.

Cygański wróżbita. (1924, październik 26). Ilustrowany Kuryer Codzienny, s. 8.

Mściwi cyganie. (1924, grudzień 14). Ilustrowany Kuryer Codzienny, s. 7.

Koronacja króla Michała II w Piastowie pod Warszawą. (1925, styczeń 25). Ilustrowany Kuryer Codzienny, s. 7.

Cygańska plaga. (1925, luty 12). Ilustrowany Kuryer Codzienny, s. 8.

Echa ekscesów antyżydowskich. (1926, wrzesień 6). Ilustrowany Kuryer Codzienny, s. 9.

Cyganie ludożercami. (1927, marzec 4). Ilustrowany Kuryer Codzienny, s. 12.

Cyganie-ludożercy. (1927, marzec 6). Ilustrowany Kuryer Codzienny, s. 6.

Straszne szczegóły ludożerstwa uprawiane przez cyganów. (1927, marzec 7). Ilustrowany Kuryer Codzienny, s. 12.

„Mięso rudego dziecka przynosi szczęście". (1927, marzec 8). Ilustrowany Kuryer Codzienny, s. 10.

Ludożercy z Mołdawji. (1927, marzec 9). Ilustrowany Kuryer Codzienny, s. 4.

Ludożercy z nad Wettawy. (1927, marzec 11). Ilustrowany Kuryer Codzienny, s. 4.

Nowe zbrodnie ludożerców z Koszyc. (1927, marzec 12). Ilustrowany Kuryer Codzienny, s. 4.

Dalsze szczegóły o ludożercach z Koszyc. (1927, marzec 13). Ilustrowany Kuryer Codzienny, s. 5.

Nie znają Boga nie boją się szatana. (1927, marzec 16). Ilustrowany Kuryer Codzienny, ss. 4-5.

Kanibalizm cyganów z Mołdawy udowodniony. (1927, listopad 14). Ilustrowany Kuryer Codzienny, s. 5.

Cygańska lista wyborcza. (1928, styczeń 13). Ilustrowany Kuryer Codzienny, s. 10.

Król cyganów zagrożony. (1929, lipiec 3). Ilustrowany Kuryer Codzienny, s. 7.

Interwencja „króla cyganów” w policji poznańskiej. (1930, kwiecień 20). Ilustrowany Kuryer Codzienny, s. 10.

Bitwa cyganów w Mokotowie. (1930, czerwiec 17). Ilustrowany Kuryer Codzienny, s. 4. Jego Królewska Mość Władca Cyganów w Krakowie. (1930, wrzesień 25). Ilustrowany Kuryer Codzienny, s. 7. 
Król cygański Kwiek rejestruje swych poddanych w Czechosłowacji. (1930, październik 24). Ilustrowany Kuryer Codzienny, s. 13.

Walka o tron cygański w Poznaniu. (1930, listopad 14). Ilustrowany Kuryer Codzienny, s. 5.

Rewolucja pałacowa w rodzinie króla cyganów. (1930, listopad 22). Ilustrowany Kuryer Codzienny, s. 4.

Tragedja w "królewskiej” rodzinie cyganów. (1930, grudzień 7). Ilustrowany Kuryer Codzienny, s. 12.

Jego Królewska Mość Król Kwiek w Sosnowcu. (1931, styczeń 17). Ilustrowany Kuryer Codzienny, s. 5.

Złodzieje Iwowscy czyhają na "króla cyganów”. (1931, luty 8). Ilustrowany Kuryer Codzienny, s. 18.

Moskiewscy goście u cygańskiego „króla” Kwieka. (1931, luty 12). Ilustrowany Kuryer Codzienny, s. 5.

Bratanica króla cyganów przez sąd uniewinniona. (1931, luty 18). Ilustrowany Kuryer Codzienny, s. 7.

Rozprawa "cygańska” w sądzie łódzkim. (1931, luty 20). Ilustrowany Kuryer Codzienny, s. 15.

Walka dwóch „dynastii” cygańskich. (1931, maj 8). Ilustrowany Kuryer Codzienny, s. 8.

J.K.M. król Kwiek w Zakopanem. (1932, styczeń 31). Ilustrowany Kuryer Codzienny, s. 12.

Aresztowanie adiutanta „króla cyganów” po krwawym asenterunku cygańskim. (1932, kwiecień 21). Ilustrowany Kuryer Codzienny, s. 9.

Polski "król cyganów” wydalony z Czechosłowacji. (1932, maj 30). Ilustrowany Kuryer Codzienny, s. 10.

Król cyganów polskich - wielkim przemysłowcem. (1932, czerwiec 18). Ilustrowany Kuryer Codzienny, s. 8.

Uwięzienie „wicekróla” cygańskiego za oszustwo. (1932, czerwiec 28). Ilustrowany Kuryer Codzienny, s. 13.

Prawdziwy "baron cygański”. (1932, sierpień 19). Ilustrowany Kuryer Codzienny, ss. 2-3.

Poddani obrabowali cygańskiego „króla”. (1932, sierpień 25). Ilustrowany Kuryer Codzienny, s. 13.

Michał Kwiek podróżny polski. (1932, wrzesień 20). Ilustrowany Kuryer Codzienny, s. 4.

W Hamburgu bawi grupa polskich cyganów. (1932, październik 1). Ilustrowany Kuryer Codzienny, s. 15.

Syn „króla cyganów” uniewinniony od zarzutu napadu. (1933, styczeń 9). Ilustrowany Kuryer Codzienny, s. 12.

„Kobietę która zdradza męża każe się śmiercią". (1933, styczeń 14). Ilustrowany Kuryer Codzienny, s. 11.

Gdzie zaginęła cyganka z „królewskiego rodu”. (1933, styczeń 19). Ilustrowany Kuryer Codzienny, s. 8.

Baron cygański w Krakowie wyławia fałszywe paszporty. (1933, kwiecień 9). Ilustrowany Kuryer Codzienny, s. 18.

Bratanica „króla cyganów” popełniła zamach samobójczy. (1933, lipiec 9). Ilustrowany Kuryer Codzienny, s. 12.

Napad bandytów na króla cyganów. (1933, lipiec 22). Ilustrowany Kuryer Codzienny, s. 7. Cygańsko-perskie awantury. (1933, lipiec 31). Ilustrowany Kuryer Codzienny, s. 12.

Uprowadzenie „królewny". (1933, listopad 13). Ilustrowany Kuryer Codzienny, s. 14. 
Król cygański Kwiek zakłada państwo w Afryce. (1934, luty 12). Ilustrowany Kuryer Codzienny, s. 10.

Walka cyganów w komisariacie policji i „szambelan” w pyjamie. (1934, kwiecień 23). Ilustrowany Kuryer Codzienny, s. 13.

Zjazd cyganów z całego świata na wesele następcy tronu „króla” Kwieka. (1934, czerwiec 4). Ilustrowany Kuryer Codzienny, s. 8.

„Król” cyganów Michał II Kwiek z Poznania w Rumunji. (1934, październik 20). Ilustrowany Kuryer Codzienny, s. 4.

"Jego Królewska Mość" Michał Kwiek. (1934, październik 31). Ilustrowany Kuryer Codzienny, s. 7.

Król cyganów Michał Kwiek prosi o ziemię w Afryce. (1934, listopad 7). Ilustrowany Kuryer Codzienny, s. 6.

„Król" cyganów Kwiek ofiarował pomoc policji stanisławowskiej. (1935, styczeń 6). Ilustrowany Kuryer Codzienny, s. 14.

Międzynarodowa unja cyganów. (1935, styczeń 24). Ilustrowany Kuryer Codzienny, s. 9.

Sędziowie "króla” Kwieka, którzy chcą pić za darmo. (1935, luty 8). Ilustrowany Kuryer Codzienny, s. 9.

„Wódz narodu cygańskiego". (1935, luty 14). Ilustrowany Kuryer Codzienny, s. 10.

Program „wodza narodu cygańskiego”. (1935, luty 21). Ilustrowany Kuryer Codzienny, s. 7.

Silna ręka wodza cyganów. (1935, marzec 5). Ilustrowany Kuryer Codzienny, s. 4.

Walka cyganów o "skarb królowej Saby". (1935, marzec 30). Ilustrowany Kuryer Codzienny, s. 10.

Komornik i licytacja u zdetronizowanego króla. (1935, kwiecień 13). Ilustrowany Kuryer Codzienny, s. 11.

W żałobie narodowej biorą udział cyganie. (1935, maj 17). Ilustrowany Kuryer Codzienny, s. 17.

Król mleczarzem. (1935, lipiec 30). Ilustrowany Kuryer Codzienny, s. 6.

Cyganie wybierają swojego „króla”. (1935, listopad 9). Ilustrowany Kuryer Codzienny, s. 14.

\section{Polska Zbrojna}

Zbrodnia cyganów. (1923, kwiecień 16). Polska Zbrojna, s. 4.

Krwawy dzień 1 maja w Ustrzykach. (1924, maj 8). Polska Zbrojna, s. 9.

Krwawy opór cyganów. (1924, sierpień 16). Polska Zbrojna, s. 4.

Końska padlina przyczyną morderstwa. (1926, grudzień 11). Polska Zbrojna, s. 7.

Banda cygańska przed sądem. (1928, listopad). Polska Zbrojna, s. 7.

Literatura cygańska. (1929, maj 19). Polska Zbrojna, s. 7.

Listy z Anglii. (1929, czerwiec 16). Polska Zbrojna, s. 4.

Z wędrówek po Bułgarii. (1930, grudzień). Polska Zbrojna, s. 10.

Okradzenie księcia cyganów. (1931, sierpień). Polska Zbrojna, s. 8.

Napaść na króla cyganów. (1932, sierpień 24). Polska Zbrojna, s. 7.

Tajemnica zniknięcia cygańskiej Messaliny. (1933, styczeń 13). Polska Zbrojna, s. 7.

Poszukiwania Mani Kwiek. (1933, styczeń 14). Polska Zbrojna, s. 7.

Mania Kwiek znalazła się. (1933, styczeń 19). Polska Zbrojna, s. 8.

Zielony Sztandar

Król cygański. (1932, wrzesień 11). Zielony Sztandar, 11. 